\title{
Assessment of environmental pollution level caused by shipbuilding industry
}

\section{GABRIEL-VALENTIN SERBAN $^{1,2}$, MARCELA NICULESCU ${ }^{1}$, VASILE IANCU ${ }^{1}$, IULIANA PAUN $^{1}$, FLORINELA PIRVU ${ }^{1}$, CATALIN MANEA ${ }^{3}$, FLORENTINA LAURA CHIRIAC ${ }^{1 *}$, GABRIELA GEANINA VASILE ${ }^{1}$}

\author{
${ }^{1}$ National Research and Development Institute for Industrial Ecology - ECOIND, 57-73 Drumul Podu Dambovitei, \\ Sector 6, 060652, Bucharest, Romania \\ ${ }^{2}$ University Politehnica of Bucharest, 313 Splaiul Independentei, sector 6, 060042, Bucharest, Romania \\ ${ }^{3}$ National Research and Development Institute for Industrial Ecology - ECOIND, Ramnicu Valcea Branch, 182 Stirbei \\ Voda Street, 240588, Romania \\ *Corresponding author: florentina.chiriac88@gmail.com
}

$\begin{array}{lll}\text { Received: } & \text { Accepted: } & \text { Published: } \\ \text { 29.09.2021 } & 16.11 .2021 & 17.12 .2021\end{array}$

\begin{abstract}
The purpose of the paper was to create databases that would allow a proper assessment of the degree of marine pollution generated by shipyard industrial sector. The study was conducted over a period of three years, between 2015 and 2017. The parameters determined for the waters collected from the shipyard were within the maximum allowed limits according to the norms in force. However, values very close to the maximum allowable limit were observed in the case of groundwater for nickel, determined from the drilling located near the fuel depot in 2015 and chlorides determined from the drilling located near the galvanizing workshop, both in 2016 and in 2017. The analyzed parameters for the soil samples, collected from various sampling points and different depths, were below the value of the alert thresholds for less sensitive soils, according to Order 756/97. The databases created for this study can contribute as an incipient basis for the development of larger studies that include other industrial sectors as well as a longer evaluation period.
\end{abstract}

Keywords: shipbuilding industry, organic and inorganic contaminants, seawater quality, soil, environmental status

\section{INTRODUCTION}

Ports have always been a gateway to the world, increasing social development, trades and cultural exchange. Thus, they were an essential factor for the global economy, concentrating a large population around them. However, coastal structures that protect maritime transport activities in ports have also created significant problems for the coastal environment, disrupting normal patterns of water and sediment circulation, leading to the coastal environment pollution. Although they can be considered fundamental centers for regional economic activity in an area, ports are a major source of pollution. The port related-industries have a significant impact regarding the quality of the environment. However, a special contribution is the anthropogenic pollution caused by the discharge of effluents from wastewater treatment plants in the marine ecosystem. Thus, the effluent components, such as persistent organic pollutants, sediments, inorganic nutrients and heavy metals, can have serious consequences on marine ecosystems [1]. In this case, the indirect effects of chemical pollution have negative implications for the marine environment [2].

Coastal sediments are the first to be affected mainly by anthropogenic stressors, the problems related to their management requiring the coverage of several aspects [3, 4]. Due to the many potential sources of contamination (accidental discharges from commercial vessel traffic, atmospheric deposition, agricultural and industrial discharges) or from other sources (precipitation, 
shipyards, storm-water, etc.), water and sediments in ports become vulnerable when changes occur environmental quality. Marine sediments have a high capacity to accumulate various organic pollutants from heavily industrialized sectors, they act as deposits for various contaminants of aquatic systems.

Heavy metals and persistent organic pollutants require special attention when considering the quality of marine ecosystems. The behavior of these two types of pollutants in the marine environment is influenced by different factors. For example, hydrocarbons can be oxidized and decomposed due to bacterial activity. Heavy metals, on the other hand, do not decompose and accumulate easily in sediments. Heavy metals can affect the ecological balance for various aquatic organisms (vertebrate and invertebrate species and aquatic plants), being considered harmful to species that are part of the food chain to humans, due to their ability to bioaccumulate and biomagnify [5].

In recent years, more and more studies have reported the accumulation of heavy metals in various species of aquatic plants and in fish tissue worldwide $[6,7]$. The level of concentrations of heavy metals in aquatic environments (e.g. water and sediments) can be an indicator of the ecological background and magnification along the food chain [8-10]. Among the most important anthropogenic activities, dredging and removal of dredged sediments are probably the most significant causes of marine pollution. Dredging is an important activity for most ports in terms of navigation, civil works, food control, removal of contaminated sediments and beach nourishment [11]. However, in general, dredged sediments are polluted and considered residual waste. Thus, special attention was paid to the development of a sustainable management of dredging environment [12]. A series of investigations, together with field experiments conducted in countries such as the Netherlands, Belgium, Germany, United States and Japan, have formed the basis for the design of integrated programs for the contaminated dredged sediments management [13-15].

Throughout time, studies conducted around the world have used their results to integrate data on the assessment, management and remediation of contaminated sediments [16], taking into account both socio-economic and environmental issues. Thus, a series of guidelines on sediment quality (SQG) were established (interpretation of historical data, sediment contamination assessment, contamination mitigation strategies, planning of monitoring programs and remedial actions) [1720]. The approach of contaminated sediments aims to assess the different levels of organic pollutants and heavy metals and to compare the values determined with the environmental standards in force. They aimed to develop a series of SQGs to correlate different levels of concentration of chemical pollutants in sediments with their potential on biological effects. Chemicals are usually present in the form of mixtures, so their cumulative effects on marine sediments are difficult to predict [21]. Aquatic ecosystems must be periodically investigated for a more up-to-date assessment of water and sediment quality, by monitoring all heterogeneous factors: chemical and physical characterization of the habitat, ecotoxicological tests, and biological research [22].

In the shipbuilding industry, the direct impact on the environment involves the construction, maintenance and repair of ships. Major environmental pollution is mainly due to the shipbuilding stage, but, in addition, maintenance and repair operations also contribute to increasing the level of pollution. The main activities responsible for the gradual pollution of the environment and the main contaminants generated by them are:

- Surface treatment operations: wastewater contaminated with paint chips, solvents for cleaning and removing paints, surface contaminants and bilge oil residues;

- Painting and plastering: contamination of waters with zinc, organic substances and solvents (paint), release of dangerous and toxic vapors and leaks of paints when the process is performed on the wet surface;

- Repair and maintenance of ships: pollution of waters and soils with oil.

The aim of this study was to create a database, collecting data over a period of three years (2015-

2017) to assess marine pollution generated by the shipping industry in Romania.

\section{MATERIAL AND METHODS}


Sampling points and environmental factors analyzed

The water and soil samples as well as the parameters determined for establishing the degree of pollution were selected according to the norms in force as well as the specifics of the field of activity carried out. Thus, wastewater before evacuation in the urban network was collected Quarterly, clean water from fire extinguishing ring and doc launch were collected every six months, while rainwater (from rainwater drain) and groundwater (from the drillings located in the vicinity of the fuel depot and the galvanizing workshop) samples were collected annually. The analyzed organic and inorganic parameters for water samples are given in Table 1, together with the corresponding reference values and the standardized methods used.

Table 1. Organic and inorganic parameters determined for water sample matrices

\begin{tabular}{l|ccccl}
\hline \multicolumn{1}{c}{ Parameters } & M.U. & Wastewater & Rainwater & Groundwater & Standardized method \\
\hline $\mathrm{pH}$ & $\mathrm{pH} \mathrm{units}$ & $6.5-8.5$ & $6.5-8.5$ & $6.5-8.5$ & SR EN ISO 10523:12 \\
Suspended solids & $\mathrm{mg} / \mathrm{L}$ & 350 & 60 & - & SR EN 872:05 \\
BOD 5 & $\mathrm{mgO}_{2} / \mathrm{L}$ & 300 & - & - & SR EN 1899-1:2003 \\
COD & $\mathrm{mgO} / \mathrm{L}$ & 500 & 125 & 125 & SR EN ISO 6060:96 \\
Ammonium & $\mathrm{mg} / \mathrm{L}$ & 30 & - & 30 & SR ISO 7150-1:2001 \\
Total phosphorus & $\mathrm{mg} / \mathrm{L}$ & 5 & - & - & SR EN ISO 6878:2005 \\
Lead & $\mathrm{mg} / \mathrm{L}$ & 25 & - & - & SR 7587:1996 \\
Zinc & $\mathrm{mg} / \mathrm{L}$ & 1 & - & - & SR EN ISO 11885:2009 \\
Total oil and grace & $\mathrm{mg} / \mathrm{L}$ & 0.5 & 20 & 20 & SR EN ISO 11885:2009 \\
Petroleum products & $\mathrm{mg} / \mathrm{L}$ & 5 & 5 & - & SR 7877-2:1995 \\
Total residue & $\mathrm{mg} / \mathrm{L}$ & - & 2000 & - & STAS 9187-1984 \\
Nickel & $\mathrm{mg} / \mathrm{L}$ & - & - & 0.008 & SR EN ISO 11885:09 \\
Chromium & $\mathrm{mg} / \mathrm{L}$ & - & - & 0.004 & SR EN ISO 11885:09 \\
Copper & $\mathrm{mg} / \mathrm{L}$ & - & - & 0.00003 & SR EN ISO 11885:09 \\
Manganese & $\mathrm{mg} / \mathrm{L}$ & - & - & 0.769 & SR EN ISO 11885:09 \\
Zinc & $\mathrm{mg} / \mathrm{L}$ & - & - & 0.177 & SR EN ISO 11885:09 \\
Lead & $\mathrm{mg} / \mathrm{L}$ & - & - & 0.018 & SR EN ISO 11885:09 \\
Chloride & $\mathrm{mg} / \mathrm{L}$ & - & - & 160 & SR 7587:96 \\
\hline
\end{tabular}

* Integrated Environmental Authorization for a shipyard

Table 2. Organic and inorganic parameters determined for water sample matrices

\begin{tabular}{|c|c|c|}
\hline $\begin{array}{c}\text { Sampling } \\
\text { point }\end{array}$ & Parameter & Standardized method \\
\hline $\begin{array}{l}\text { F1 } \\
\text { F2 } \\
\text { F3 }\end{array}$ & $\begin{array}{l}\text { Total chromium } \\
\text { Copper } \\
\text { Manganese } \\
\text { Nickel } \\
\text { Zinc } \\
\text { Total petroleum hydrocarbons }\end{array}$ & $\begin{array}{l}\text { SR ISO 11047:1999 } \\
\text { PIS-08 Ed5, R0 }\end{array}$ \\
\hline $\mathrm{F} 4$ & $\begin{array}{l}\text { Cadmium } \\
\text { Lead }\end{array}$ & SR ISO 11047:1999 \\
\hline F5 & $\begin{array}{l}\mathrm{pH} \\
\text { Benzene, Toluene, Ethylbenzene and Xylenes (BTEX), } \\
\text { phenols } \\
\text { Polycyclic aromatic hydrocarbons (PAHs) } \\
\text { Total petroleum hydrocarbons }\end{array}$ & $\begin{array}{l}\text { SR EN 15933:13 } \\
\text { SR EN ISO 22155:13 } \\
\text { SR ISO 14154:07 } \\
\text { ISO 13859:14(E) } \\
\text { PIS-08 Ed5, R0 }\end{array}$ \\
\hline
\end{tabular}

The soil samples were collected with an annual frequency, at $10 \mathrm{~cm}$ and $30 \mathrm{~cm}$ depth, from five locations situated on the shipyard site (F1-F5). The analyzed organic pollutants along with the metal ions for soil samples are given in Table 2, together with the standardized methods used. 
The parameter values determined for the wastewater discharged in the urban network in the 20152017 period were within the limits allowed by the Integrated Environmental Authorization. Although in the limit, variations of total phosphorus, zinc and petroleum products were noticed in the studied period, the parameters zinc and total phosphorus registering higher values in 2016 compared to 2015 and 2017, the largest being registered in the quarters I and IV, for total phosphorus and quarters I and II, for zinc. The highest values of the total oil and grace parameter were observed in the first quarter of 2017 and the second quarter of 2016 (Figure 1).

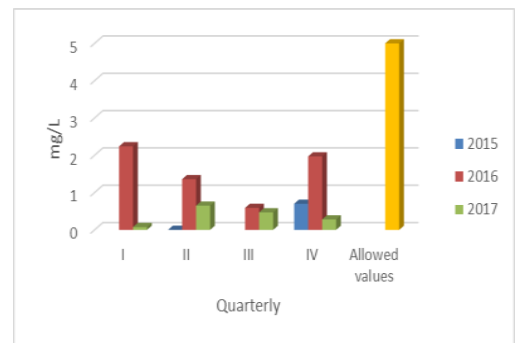

a)

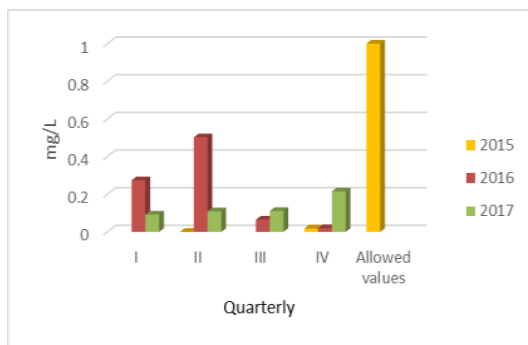

b)

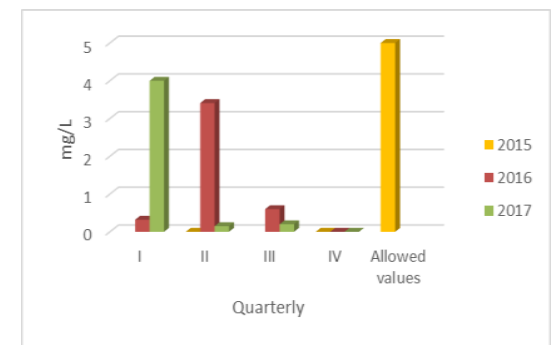

c)

Fig. 1. Variation of total phosphorus (a), zinc (b) and petroleum products (c) during the monitoring period

For the conventionally clean water samples, the determined parameters were within the maximum admissible limits.

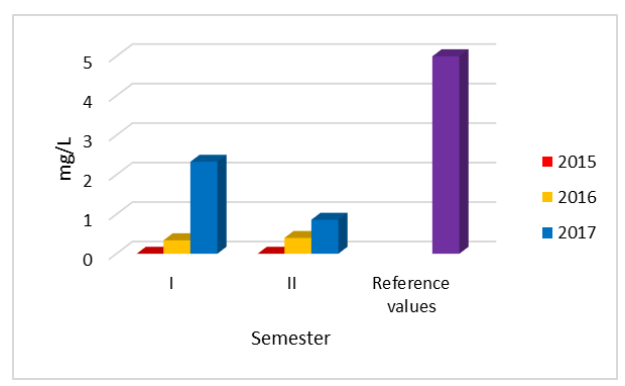

a)

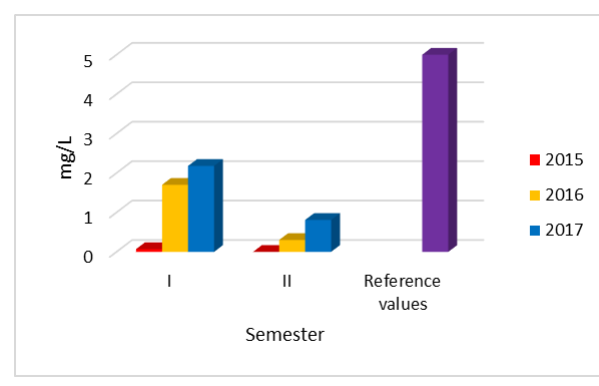

b)

Fig. 2. Variation of the petroleum products determined in the clean water samples during the monitoring period: a) fire extinguishing ring; b) launch dock

For the total oil and grace parameter higher values were observed in the first semester of 2017 for both samples, but also in the first semester of 2016 for the water taken from the Ship Launching Dock (Figure 2).

The rainwater did not register exceedances nor important variations of the values of the determined parameters. The groundwater, taken with an annual frequency, did not exceed the analyzed indicators, but values close to the limit imposed were determined for nickel in 2015, for the drilling located near the fuel depot and significant variations in 2015 and 2016 for the drilling located near the galvanizing workshop. Higher values were also reported for the manganese, in 2016 for the fuel depot, but also values close to the allowed limit for chlorides in 2016 and 2017 for the drilling located near the galvanizing workshop (Figure 3).

For soil samples collected from various sampling points and different depths, the results obtained for the analyzed parameters were below the value of the alert thresholds for less sensitive soils, according to Romanian Order 756/97 [23]. The highest values were recorded for the petroleum products parameter, determined for the sample F4 taken at both depths, in 2015 (Figure 4). 


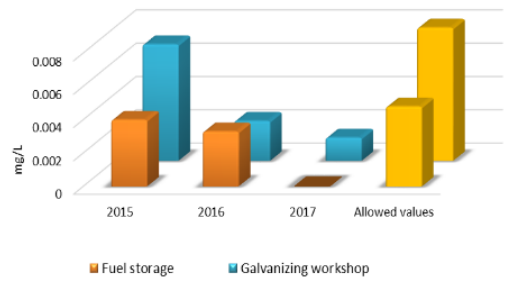

a)

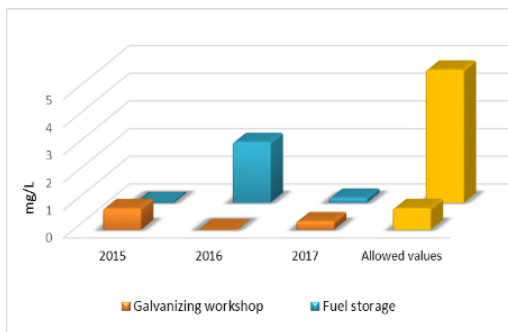

b)

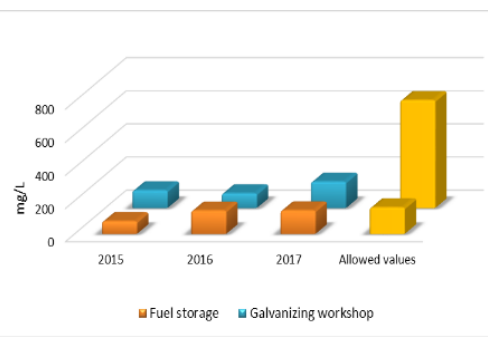

c)

Fig. 3. Variation of nickel (a), manganese (b) and chloride (c) values determined in groundwater during the monitoring period

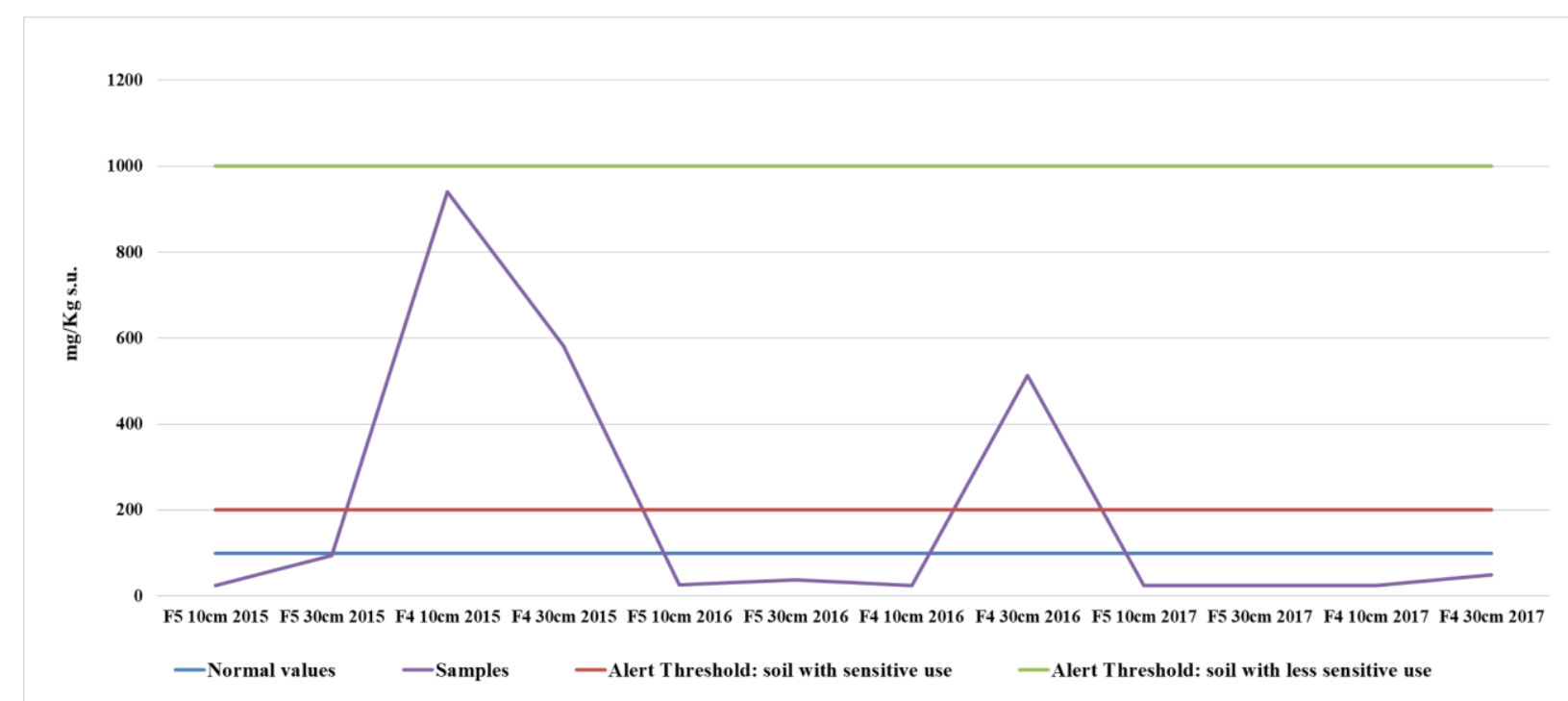

Fig. 4. Variation of petroleum product values determined in soil samples collected between 2015 and 2017

For soils F1, F2 and F3, the highest values were identified for sample F2 taken at $10 \mathrm{~cm}$ in 2015 and F3 taken at $30 \mathrm{~cm}$ in 2016 for the nickel, while concentrations very close to the soil alert threshold less sensitive were determined for the zinc in 2015 (Figure 5).

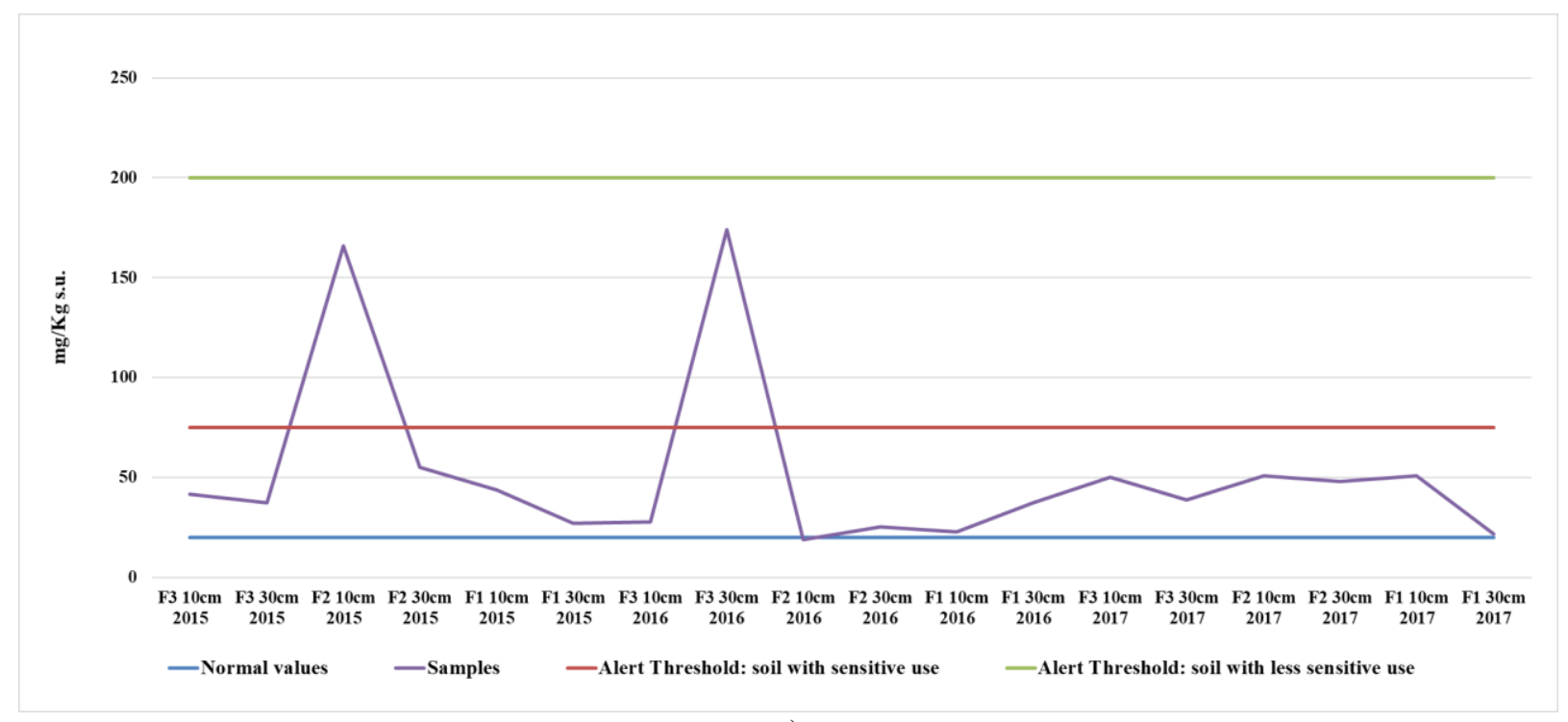

a) 


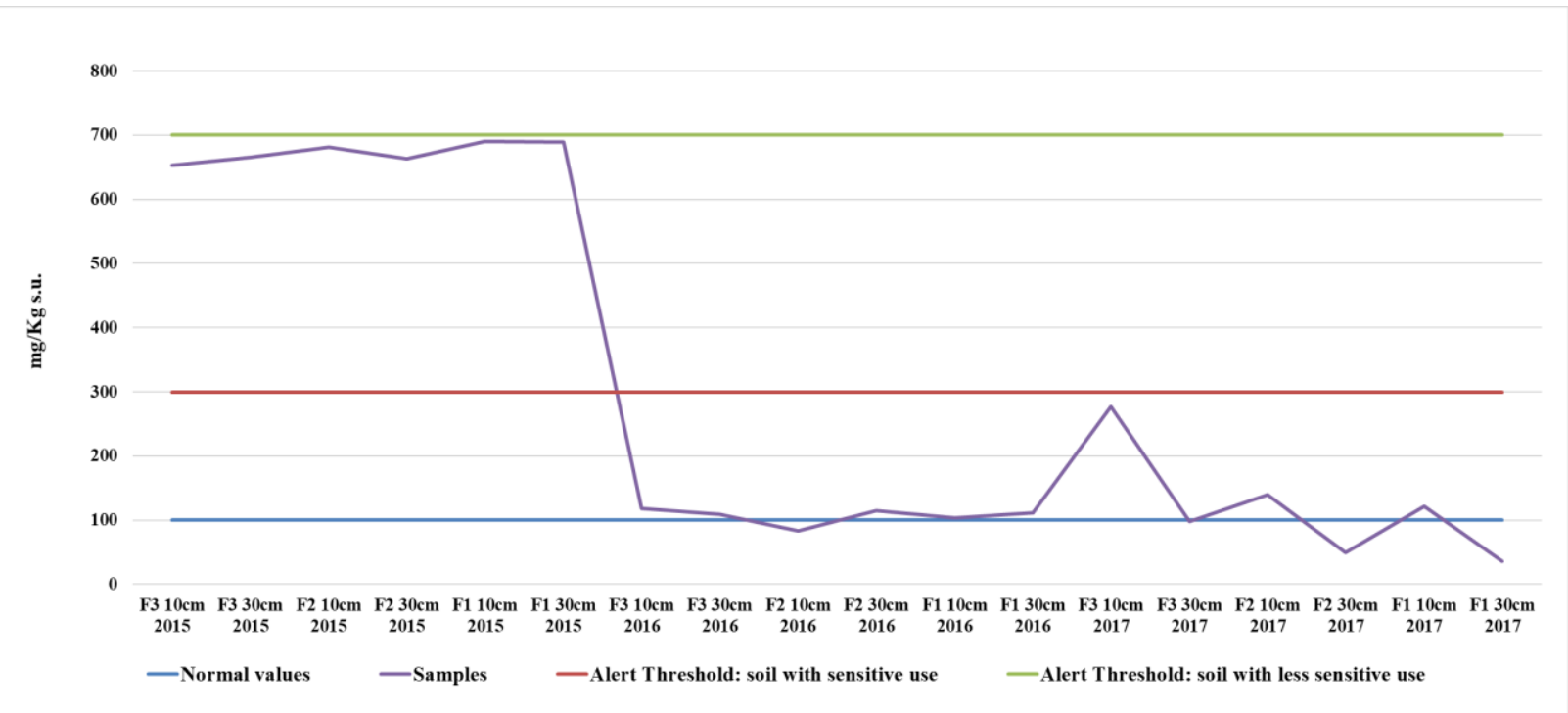

b)

Fig. 5. Variation of nickel (a) and zinc (b) values determined soil samples collected between 2015 and 2017

\section{CONCLUSIONS}

The purpose of the paper was to create databases that would allow a proper assessment of marine pollution generated by various industrial sectors. To assess the degree of marine pollution generated by shipyards, water samples (wastewater, clean water, rainwater and groundwater) and soil were taken from such a site. The study was conducted over a period of three years, between 2015 and 2017.

The parameters determined for the water samples collected did not exceed the maximum allowed limits according to the norms in force. However, values very close to the maximum admissible limit were observed for nickel in groundwater samples collected from the drilling located near the fuel depot in 2015 and chlorides in the drilling located near the galvanizing workshop, both in 2016 and in 2017. The analyzed parameters for the soil samples, taken from various sampling points and different depths, were below the value of the alert thresholds for less sensitive soils, according to Romanian Order 756/97.

The databases created in this study will contribute as an incipient basis for the development of larger studies that include other industrial sectors as well as a longer evaluation period.

\section{REFERENCES}

[1] RIECHERS, M., BRUNNER, B.P., DAJKA, J.C., DUSE, I.A., LUBKER, H.M., MANLOSA, A.O., SALA, J.E., SCHAAL, T., WEIDLICH, S., Mar. Pollut. Bull., 167, 2021, p. 112263.

[2] ALAM, M.W., XIANGMIN, X., AHAMED, R., Environmental Challenges, 4, 2021, p. 100154.

[3] GHARIBREZA, M., HABIBI, A., IMAMJOMEH, S.R., ASHREF, M.A., Catena, 122, 2014, p. 150.

[4] ZULKIFLEY, M.T.M., FATT, N.T., ABDULLAH, W.H., RAJ, J.K., PARAM, S.P., HASHIM, R., ASHRAF, M.A., Cent. Eur. J. Geosci., 5, no. 2, 2013, p. 285-314.

[5] MANAHAN, S.E., Environmental Chemistry. Seventh Edition, Lewis Publishers, New York, London, Washington, CRC Press LLC, 2000, p. 1-898.

[6] BAKAR, A.F.A., YUSOFF, I., FATT, N.T., OTHMAN, F., ASHRAF, M.A., BioMed Res. Int., 2013, p. 1.

[7] ASHRAF, M.A., MAAH, M.J., YUSOFF, I., Int. J. Environ. Res., 6, no. 1, 2012, p. 209.

[8] GHARIBREZA, M., RAJ, J.K., YUSOFF, I., OTHMAN, Z., TAHIR, W.Z.W.M., ASHRAF, M.A., J. Radioanal. Nucl. Chem., 295, 2013, p. 1715.

[9] GHARIBREZA, M., RAJ, J.K., YUSOFF, I., OTHMAN, Z., TAHIR, W.Z.W.M., ASHRAF, M.A., Geosci. J., 17, no. 2, 2013, p. 211. 
[10] GHARIBREZA, M., RAJ, J.K., YUSOFF, I., OTHMAN, Z., TAHIR, W.Z.W.M., ASHRAF, M.A., Soil Till. Res., 131, 2013, p. 1.

[11] BORTONE, G., AREVALO, E., DEIBEL, I., DETZNER, H.-D., PROPRIS, L., ELSKENS, F., GIORDANO, A., HAKSTEGE, P., HAMER, K., HARMSEN, J., HAUGE, A., PALUMBO, L., VEEN J., J. Soils Sediments, 4, no. 4, 2004, p. 225.

[12] APITZ, S.E., POWER, E.A., J. Soil Sediments, 2, no. 2, 2002, p. 61.

[13] DONAZAR-ARAMENDIA, I., SANCHEZ-MOYANO, J.E., GARCIA-ASENCIO, I., MIRO, J.M., MEGINA, C., GARCIA-GOMEZ, J.C., Mar. Pollut. Bull., 161, 2020, p. 111736.

[14] CHU, S.H., YAO, J.J., J. Clean. Prod., 274, 2020, p. 122673.

[15] AVERETT, D.E., Tetra Tech Inc., Miscellaneous Paper EL-94-1, U.S. Army Engineer Waterways Experiment Station, Vicksburg, MS, 1994.

[16] BURTON Jr., G.A., Limnology, 3, 2002, p. 65.

[17] LONG, E., MAC, DD., SMITH, S., CALDER, F., Environ. Manage., 19, 1995, p. 81.

[18] MAC DONALD, D., INGERSOLL, C., BERGER, T., Arch. Environ. Con. Tox., 39, 2000, p. 20.

[19] BAY, S.M., RITTER, K.J., VIDAL-DORSCH, D.E., FIELD, L.J., Integr. Enviro. Assess. Manage., 8, 2012, p. 597.

[20] BEEGAN, C., BAY, S. M., Integr. Enviro. Assess. Manage., 8, 2012, p. 586.

[21] WENNING, R.J., BATleY, G.E., INGERSOLL, C.G., MOORE, D.W., Pensacola. FL: Society of Environmental Toxicology \& Chemistry Press, 2005 (Eds).

[22] CHAPMAN, P.M., Sci. Total. Environ., 97-98, 1990, p. 815.

[23] Order no. 756 from November 3, 1997 for the approval of the Regulation on the assessment of environmental pollution.

Citation: Serban, G.-V., Niculescu, M., Iancu, V., Paun, I., Pirvu, F., Manea, C., Chiriac, F.L., Vasile, G.G., Assessment of environmental pollution level caused by shipbuilding industry, Rom. J. Ecol. Environ. Chem., 2021, 3, no.2, pp. 107-113.

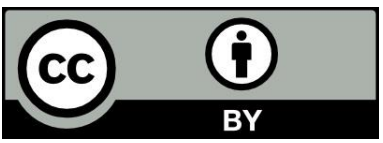

(C) 2021 by the authors. This article is an open access article distributed under the terms and conditions of the Creative Commons Attribution (CC BY) license (http://creativecommons.Org/licenses/by/4.0/). 